\title{
A Review of Adverse Effects and Benefits of Nitrate and Nitrite in Drinking Water and Food on Human Health
}

\author{
Mina Parvizishad, ${ }^{1}$ Arash Dalvand, ${ }^{2}$ Amir Hossein Mahvi, ${ }^{1,3,}{ }^{*}$ and Fatemeh Goodarzi ${ }^{1}$ \\ ${ }^{1}$ Department of Environmental Health Engineering, School of Public Health, Tehran University of Medical Sciences, Tehran, Iran \\ ${ }^{2}$ Environmental Science and Technology Research Center, Department of Environmental Health Engineering, School of Public Health, Shahid Sadoughi University of Medical \\ Sciences, Yazd, Iran \\ ${ }^{3}$ Center for Solid Waste Research, Institute for Environmental Research, Tehran University of Medical Sciences, Tehran, Iran \\ "Corresponding author: Amir Hossein Mahvi, Department of Environmental Health Engineering, School of Public Health, Tehran University of Medical Sciences, Tehran, Iran. \\ Tel: +98-9123211827, Fax: +98-2166744339, E-mail: ahmahvi@yahoo.com
}

Received 2016 July 09; Revised 2016 September 27; Accepted 2016 November 20.

\begin{abstract}
Introduction: The problem related to water pollution of nitrates and nitrites is both an issue in Iran and also most parts of the world. Studies to evaluate the acute and chronic effects of nitrate and nitrite have demonstrated that different concentrations of these compounds in water and food have been causing multiple diseases.

Methods: In this paper, researchers reviewed published articles and research from 1950 to 2016 in English and Farsi, according to key words "nitrate”, "nitrite”, "water", “food” and "health effects”, retrieved from databases, such as Medline, Scopus, Pub Med, and scientific information database (SID).

Results: Consumption of drinking water and food containing high concentrations of nitrate and nitrite could cause diseases, such as cancer, methemoglobinemia, and enlargement of the thyroid gland and diabetes mellitus. The positive effects of low concentrations of nitrates and nitrites include a protective effect on the cardiovascular system, regulatory role in blood pressure, and homeostasis (also static) of the vessels

Conclusions: As different concentrations of nitrates and nitrites have beneficial and undesirable effects on human health and regarding the high cost of treating water contaminated with nitrite and nitrate, more investigations should be done in setting the standards and levels of parameters used in drinking water.
\end{abstract}

Keywords: Nitrate, Nitrite, Drinking Water, Food, Health Effects

\section{Introduction}

The contamination of surface water and groundwater with nitrate and nitrite has been considered not only in Iran, but also in most urban and rural areas of the word. Surface water and groundwater resources in cities, such as Semnan, Tehran, Mashhad, Rasht, Sari, Hamedan, Arak and Isfahan, have this problem and nitrate concentrations in some of these areas are on the rise with further industrialization of the cities (1). Pollution of underground water in rural areas in New York (2), India (3, 4), Argentina (5), and Iowa (America's) (6), North China (7) shows that this problem is not unique to Iran and in general, human activities including agricultural activities $(8,9)$, purification and sanitation $(10,11)$, diffusion from industrial processes and disposal of solid waste (12) are the most common sources of nitrate and nitrite pollution (13). Different optimized methods such as nano-filtration (14) and ion exchange resins (15) in water and horizontal roughing filter (16) in wastewater have been studied by researchers to reduce levels of these contaminants. The maximum allowable concentration of nitrate and nitrite in order to prevent methaemoglobinaemia has been set by the world health organization (WHO). Furthermore, this guideline could be used only for public water systems. However, the spread of studies on acute and chronic effects of nitrate and nitrite in various parts of the world have shown that different concentrations in water and nutrients lead to several diseases in different groups of the population.

So far, a comprehensive research about the positive and negative effects of nitrate and nitrite in food and drinking water has not been accomplished on human health in Iran. In this paper researchers reviewed studies that have been conducted on the health effects of nitrate and nitrite in previous years. Also, the benefits and adverse effects of different concentrations of nitrate and nitrite on human health are investigated to compare the maximum concentration of nitrates and nitrites that could cause adverse effects on human health, with guidelines that have already been set by the world health organization (WHO).

The aim of this study was to review the adverse effects and benefits of nitrate and nitrite in drinking water and food on human health through reviewing prior researches. 


\section{Methods}

\subsection{Searches}

The required data for conducting the present research were gathered by search in databases, such as Medline, Scopus, Pub Med, and Scientific Information Database (SID). Published articles and research from 1950 to 2016 in English or Persian (75 articles) were retrieved.

\subsection{Study Selection and Eligibility Criteria}

Articles were selected according to the key words "nitrate", "nitrite", "water", "food" and "health effects". Among all articles found according to keywords and time limitation, articles related to identifying and removing nitrites from drinking water and wastewater were excluded from this study. Studies that were related to human exposure to sources of these pollutants, according to the content of the studies and references, were used. Studies of health effects of nitrate and nitrite on animal and other creatures were excluded and the health effects on humans were divided to 2 categories, desirable and adverse effects.

\subsection{Quality Assessment and Data Extraction}

Qualitative criteria, such as type of study (case-control or cohort study), duration of study and population were considered as other confounding factors. The flowchart of this study is presented below.

\section{Sources of Human Exposure to Nitrates and Nitrites}

Humans can be exposed to nitrates and nitrites through food, drinking water, air, and soil. The main way of nitrate and nitrite exposure to the general population is through ingestion of food and drinking water; about 5 to $8 \%$ of ingested nitrate is reduced to nitrite by bacteria in the mouth (17). Nitrate formed by the reduction of nitrate contains about $80 \%$ of the total exposure of nitrite and the remainder directly enters the body from external sources (18).

\subsection{Drinking Water}

Agricultural drainage, leachate from waste pile, and pollution from human and animal waste, are responsible for a vast increase of nitrate concentrations in surface water and groundwater (19). In general, nitrate concentrations in well water are higher than surface water sources (19). For example, very high concentrations of nitrates of more than $467 \mathrm{mg} / \mathrm{lit}$ were found in the state of Ontario in America (20) and high concentration of $1063 \mathrm{mg} / \mathrm{lit}$ was found in Manitoba. In Colombia, more than $45 \mathrm{mg} / \mathrm{lit}$ of nitrate concentrations in excess of $60 \%$ of the 450 groundwater samples was observed. The average concentration of nitrate in groundwater of Columbia between 1975 and 1990 has gradually increased, along with the increase in population and agriculture activities (19).

\subsection{Food}

Nitrate and nitrite are naturally present in many foods, and are found in some foods as additives. Vegetables and processed meats are major sources of these compounds in the diet. Nitrates and nitrites are added as preservatives to prevent the growth of bacteria Clostridium botulinum or as promoters of some food colors. Also, the high nitrate concentrations in the rage of 200 to $250 \mathrm{mg}$ per $\mathrm{Kg}$ are found in fruits and vegetables (21). Vegetables are a major source of nitrate that provide more than $85 \%$ of the average nitrate in the human diet (22). Lettuce, spinach, red beets, fennel, cabbage, parsley, carrots, celery, potatoes, cucumbers, radishes, and leeks are vegetables that contain high concentrations of nitrate (23). Nitrite concentrations in fruits and vegetables is less than nitrate and is about 10 ppm and rarely reaches more than $100 \mathrm{mg}$ per $\mathrm{Kg}$ in vegetables that have been corrupted or improperly stored or pickled; nitrate concentrations may reach more than 400 mg per $\mathrm{Kg}(24)$. Fresh meat normally contains low concentrations of nitrate and nitrite (25). Although meat and processed products contain higher concentrations of nitrite and nitrate, its concentration depends on the concentration of substances that are added as preservatives to these products as well as the method of processing (22).

\subsection{Air}

Atmospheric concentrations of nitrate were measured for several years in Iceland. Annual average levels of measured aerosol for all stations varied between 0.11 and 0.36 micrograms per cubic meter (26). In the Netherlands, monthly average nitrate concentrations were measured in the atmosphere between summer 1979 and winter 1986, and the concentrations was reported in the range of 1.5 to 9.1 micrograms per cubic meter (27).

\subsection{Soil}

No information about public exposure to nitrates and nitrites in soil has been reported by previous articles. Although nitrate is highly soluble in the soil, it is kept weakly by the soil and leaks into groundwater and surface water (24). A study at the national level in some agricultural areas of Canada was carried out to evaluate the potential risk of water pollution by high concentrations of nitrogen in the soil, and findings revealed that the concentration of nitrate in drainage water may reach levels higher than $10 \mathrm{mg}$ 
per liter of nitrate due to the presence of too much nitrogen in the soil (28).

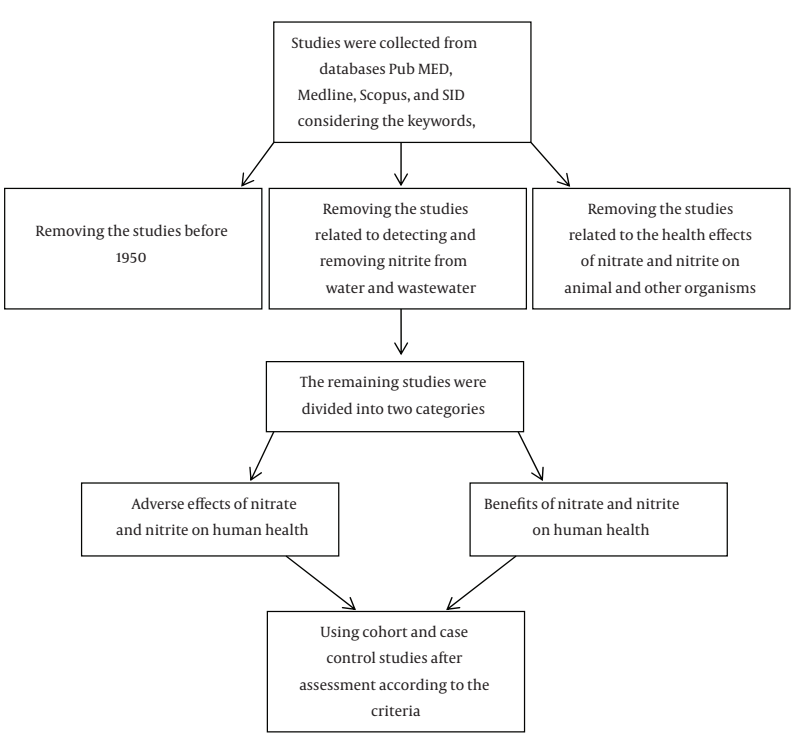

Figure 1. The Flowchart of This Study

\section{The endogenous Formation of N-Nitroso Com- pounds}

Nitrates have been known as a precursor for the formation of N-nitroso compounds. Placed on genotoxic substances, most of these compounds are carcinogenic to animals. Nitrate is stable in the human body and is an inert compound that can be metabolized by human enzymes. However, the activities of nitrate reduction by bacteria may convert nitrate into nitrite and other nitrogen compounds that can effect the physiological status and human health. After ingestion, nitrate is easily absorbed by the upper gastrointestinal tract. Over $25 \%$ of nitrate is actively excreted in saliva, and $20 \%$ of is converted to nitrite by bacteria in the moth (29). Under acidic conditions of the stomach, nitrite as the core of nitrous acid $\left(\mathrm{HNO}_{2}\right)$ spontaneously coverts to Nitrogen Trioxide $\left(\mathrm{N}_{2} \mathrm{O}_{3}\right)$, nitric oxide (NO), and nitrogen dioxide $\left(\mathrm{NO}_{2}\right)$. Nitric oxide is a biologically active compound that plays a role in the expansion and defense against pathogenic bacteria around the teeth (30). Nitrogen trioxide or in other words, a powerful factor of nitrous, is able to add NO+ to secondary and tertiary amines for the potential formation of carcinogenic nitrosamine compounds. Alternatively, $\mathrm{HNO}_{2}$ could be the $\mathrm{H}_{2} \mathrm{NO}_{2}$ core that reacts with the amine to form nitrosamine. At neutral $\mathrm{pH}$, nitrite can be reduced by bacteria to form NO that can react with oxygen molecules to form nitrosamine $\mathrm{N}_{2} \mathrm{O}_{3}$ compounds and $\mathrm{N}_{2} \mathrm{O}_{4}$. In addition to the formation of acid-catalyzed and catalyzed-bacteria of nitrous suppliers, NO syntheses of inflammatory cells can produce NO (31). These three nitrous androgenic mechanisms are considered to provide $40 \%$ to $75 \%$ of human exposure to nitric oxide (NOC). Other sources of human exposure are NOC in processed meat and fish, occupational exposures and tobacco products (32).

\section{Adverse Effects of Nitrates and Nitrites on Human Health}

5.1. Chronic Effects

5.1.1. Carcinogenic Effect of Nitrates and Nitrites

The general concern about long-term exposure to nitrite and nitrate is due to the formation of nitrosamine compounds as a large number of these compounds are carcinogenic. Epidemiological studies in connection with the use of nitrate and nitrite and cancer appearance have been conducted on humans. A study conducted in Taiwan showed that there was no significant correlation between the concentration of nitrate in drinking water and risk of dying from colon cancer. In the control group, the number of deaths that occurred was due to reasons other than colon cancer and in the case group the reason of death was colon cancer. Statistics gathered on deaths from 1999 to 2003 and for each of the witnesses, who were randomly selected, cases were entered that their sex, year of birth and year of death were equal with them. The odds ratio for the implementation of deaths from colon cancer for those, who were exposed to high concentrations of nitrate with a confidence interval $98 \%$ was from 0.84 to 1.14 (33). In the Netherland, Van Loon et al. found no association between nitrate levels in the body and stomach cancer and the gastrointestinal tract among males and females after 6.3 years of follow up cohort study, and further analysis of effective factor i.e. vitamin $C$ use indicated that there was no positive correlation between use of vitamin $\mathrm{C}$ and cancer non appearance (34). In the case of nitrite, Knekt et al. reported in 1999 that no positive correlation was found between nitrite consumption and the incidence of tumors of the large intestine and the stomach. The search was conducted for 24 years in a cohort study (35). Therefore, in the mentioned study, antioxidant levels used should also be considered as a factor affecting the incidence of cancer. In another casecontrol study that was performed in Italy during year 2001, the result showed that there was a high risk of gastric cancer among people, who had a higher consumption of nitrites and small amounts of antioxidants. Also, a positive correlation was found between gastric cancer and high levels of nitrate intake in the diet, while an interaction of vitamin $\mathrm{C}$ in both case-control studies was observed (36). The 
speed of the spread of various cancers was examined from 1972 to 1943, in the city of Alborg in Denmark, with an average nitrate concentration in water of about $30 \mathrm{mg}$ per liter while the adjacent cities were examined by Jenson et al. They found that the incidence of gastric cancer in the city of Alborg was slightly more abundant compared to neighboring towns. The results of this study stressed on the probable weak role of nitrate in the etiology of gastric cancer (37). Analysis of the relationship between different concentrations of nitrate in drinking water and cancer of the stomach, bladder, prostate, and colon among 258 citizens of the province of Valencia in Spain showed that mortality from gastric cancer has increased with increasing exposure to nitrate in males and females. Deaths from prostate cancer in males have also increased and relative risk for the age group of 55 to 75 years was 1.86 and for older than 75 years this was 1.8. In populations that had been exposed to high concentrations of nitrates of $50 \mathrm{mg}$ per liter, the relative risk for gastric cancer in the age group of 55 to 75 years for males and females was 1.91 and 1.81, respectively (38). In a study conducted in Slovakia, Hodgkin's Lymphoma and colorectal cancer incidence was observed among males and females who were exposed to water containing high concentrations of nitrate ( 4.5 to $11.3 \mathrm{mg}$ of nitrate nitrogen per liter) (39). In a similar study, no association was found between high concentrations of nitrate and bladder or kidney cancer incidence. In contrast, negative results associated with the incidence of Hodgkin's Lymphoma were found in America (40). While in Sardinia (Italy), there was limited evidence for prevalence of Hodgkin's Lymphoma among males and no certificate in females (41). Weyer et al. analyzed the incidence of Hodgkin's Lymphoma in 2001 in a cohort study among females in America and observed a weak inverse relationship between the concentration of more than $2.46 \mathrm{mg}$ per liter of nitrate-nitrogen in drinking water and risk of Hodgkin's Lymphoma, and after taking into account the interferences the connection was more powerful (42). Different results were obtained from casecontrol studies on both males and females by Ward et al. in America. The average concentration of nitrate in drinking water was greater than $4 \mathrm{mg}$ of nitrate per liter as nitrogen. There was a dose-response relationship and twice increase of the risk of Hodgkin's Lymphoma associated with exposure to the highest nitrate concentrations in drinking water and the connection remains with the consideration of confounding factors, such as vitamin $\mathrm{C}$ and carotene. The researchers concluded that long-term exposure to high concentrations of nitrates in drinking water could lead to an increased risk of Hodgkin's Lymphoma. As part of the same study, the concentration of nitrates in private wells with Hodgkin's Lymphoma risk, have been considered irrelevant when taking into account the intervening pesti- cides (43). In general, most studies have shown that nitrate concentrations in drinking water have no association with Hodgkin's Lymphoma, or have reduced it. In general, it can be said that taking interferences such as vitamin $C$ and carotene has weakened the relationship between nitrate in the diet and the incidence of Hodgkin's Lymphoma (43). A positive association was found between bladder cancer and nitrate in drinking water in a case-control study; concentrations less than or equal to $2.86 \mathrm{mg}$ per liter of nitrate as nitrogen (44). Also, Weyer et al. conducted a cohort study and their findings indicated that when the nitrate concentration was more than $2.46 \mathrm{mg}$ per liter of nitrate as nitrogen, this positive association was observed (42). However, no association was observed between bladder cancer and nitrate in drinking water in a case-control study by Weyer in 2003 (45) or a cohort study by Zeeger et al. (46). Nitrate levels in this study were more compared with the studies mentioned at the beginning and have shown a positive association. Vitamin C intake had no significant impact on the results of 2 previous studies. Vitamin E and smoking have not been effective on the results of Zeeger's study. Volkmeet et al. evaluated the effect of nitrate concentrations in drinking water on the prevalence of urinary tract cancer in Germany in 2 groups that were exposed to different concentrations of nitrate ranging from 10 to $60 \mathrm{mg}$ per liter, in 2005. In the groups that had greater exposure, a positive correlation was found between urinary tract in both genders, and a negative correlation was found with testicular tumor and no association with kidney. Penile and prostate cancer were observed (47). In a case-control study conducted by Werd in 2003 no association was found between tumor of urinary tract in both male and female groups consuming plant and animal sources containing nitrites. Among males, the highest quartile of nitrite from plant sources was associated with average risk of infection ( $\mathrm{OR}=1.3 ; 95 \% \mathrm{CI}=1.0-1.6)$ yet no process changed the risk of infection at the same time as the increase in concentration (45).

A population-based case-control study in kidney cell cancer incidence was conducted in the state of Iowa during the years 1989 to 1986, indicating that the number of sources of drinking water was increasing. The average nitrate level and years of use from a public source of drinking water with nitrate concentrations above $5 \mathrm{mg}$ per liter and less than $10 \mathrm{mg}$ per liter were calculated, respectively. No relationship was observed between renal cell carcinoma and nitrate concentration. Although exposure to high concentrations of nitrate led to a risk of infection in those who consumed abundant amounts of red meat and less amounts of vitamin $C$ in their diets, this study showed that more studies should be carried out taking into consideration the influence of dietary, nitrite and nitrate concentra- 
tions in drinking water (48).

It is hypothesized that exposure to nitrosamines increases the risk of glioma (brain stem tumor). The relationship between meat consumption, nitrates and nitrites input and two nitrosamines (nitrous dimethyl amine and Nitrosopyrrolidine) and glioma risk was investigated in a prospective cohort study. Finally, the results showed that the risk of glioma increased in people, who had consumed huge amounts of processed meats (49). The relationship between nitrite and nitrate intake and pancreatic cancer has been studied, the results showed that there was no relationship between the use of nitrate and nitrite and pancreatic cancer in males and females and there was relatively little evidence about the relationship between pancreatic cancer and processed meat consumption (50).

\subsection{Acute Toxicity}

\subsubsection{Methemoglobinemia}

A wide range of lethal concentrations of nitrite and nitrate to humans (probably because of the varying sensitivity) have been reported. For nitrate, the lethal dose is 4 to 50 grams (51) and from 67 to $833 \mathrm{mg}$ per $\mathrm{kg}$ of body weight (52) and for nitrite the lethal dose has been set as 1.6 to 9.5 grams (53) and from 33 to $250 \mathrm{mg}$ per $\mathrm{kg}$ of body weight. Lower concentrations in children and the elderly and those with reduced in reeducates met hemoglobin, cytrochrome b5 nicotinamide adenine dinucleotide has led to adverse effects (52). Methemoglobinemia has the most negative effect associated with human exposure to nitrates or nitrites. The groups that were involved with met hemoglobin formation in the blood include fetuses, infants less than 6 months old, and those, who have genetic birth defects in reeducates NADH cytochrome b5 met hemoglobin.

Studies in the United States of America from 1941 to 1995 have shown that the reason of methemoglobinemia is water containing nitrate concentrations above $10 \mathrm{mg}$ per liter in nitrate by nitrogen. Despite the limitations in clinical diagnosis, studies have shown that nitrate concentrations over 45 milligrams per liter have played an important role in methemoglobinemia in infants. Cases of methemoglobinemia had been observed, especially in children younger than 6 months old, who had been fed with dried milk and drinking water with high nitrate concentrations. From 214 clinical cases with methemoglobinemia with available, none of them were done at concentrations of less than $45 \mathrm{mg}$ per liter of nitrates, and only $2 \%$ of cases occurred at concentrations of 49 to $88 \mathrm{mg}$ per liter. In fact, $80 \%$ of the infants, who were exposed to nitrate, were infected at concentrations greater than $220 \mathrm{mg}$ per liter $(54,55)$. Although infants, who were fed through breastfeeding may be exposed to concentrations of nitrite and ni- trate, methemoglobinemia usually occurs when the baby food or dried milk is prepared with drinking water contaminated with nitrate. Younger children are less sensitive than babies. Methemoglobinemia prevalence has not increased in America in 64 children of 1 to 8 years of age that used well water contaminated with nitrate at concentrations of 97 to $491 \mathrm{mg}$ per liter. In contrast, in 38 infants, who used well water containing concentrations of $44.3 \mathrm{mg}$ per liter, methemoglobinemia prevalence had increased (56). On the other hand, in the study conducted by WHO, no exact correlation was found between the impact of certain concentrations of nitrates in drinking water and the incidence of methemoglobinemia (57). In addition, methemoglobinemia could be the result of exposure to other chemicals such as sulfate, chlorite, chloramines, chlorate and drugs, such as lidocaine, benzocaine, sulfonamides and also nitroglycerin $(58,59)$.

\subsubsection{Effect on the Thyroid Gland}

A study was performed to determine the effect of nitrate on the size and function of the thyroid gland, in 1994. Two groups exposed to contaminated water with moderate and high nitrate levels were evaluated. In populations with exposure to high concentrations of nitrate, a moderate increase was observed in thyroid gland volume. This could be caused by the interaction of competition between iodine and nitrate. In this population, high levels of nitrate had caused uptake of iodine and hypertrophy (enlargement of the thyroid gland). Among those with exposure to medium and low concentrations of nitrate, no difference was observed in thyroid volume. The results showed that nitrate could effect the thyroid gland when nitrate concentration was above $50 \mathrm{mg}$ per liter (60). In addition to methemoglobinemia disease and the carcinogenic danger of nitrate, it seems the third danger that nitrate could cause is the effect on the thyroid gland and its enlargement. Other studies in Bulgaria were conducted to assess the impact of nitrate on the status of iodine ions in two population groups of pregnant females and children between 3 to 6 years of age from 2 villages in Bulgaria with high and low concentrations of nitrate in drinking water. Statistically significant differences were seen between the rate of incidence of goiter among pregnant females, who were exposed to nitrate and females, who had no exposure. In contrast, the prevalence of goiter in children, who were exposed was not statistically significant. The results of this study, determined the role of high concentrations of nitrate in drinking water as a risk factor for thyroid dysfunction in susceptible individuals (61). 


\subsubsection{Mellitus Diabetes}

Ecological studies in Colorado (in America) showed that there was a significant relationship between the prevalence of diabetes mellitus type 1 insulin-dependent and concentration of nitrate in drinking water in children under 1 year to 18 years old (62). Also, a positive correlation was found between nitrites, nitrates and nitrosamines in food and the outbreak of this disease was reported in a case-control study in 1990 and this association was seen in a group of people, who had a diet with high concentrations of nitrate in Sweden (63). The same correlation was also reported in Finland. However, in this study, the exposure to nitrate was reported as weak (64). In contrast, a significant risk has not been observed for diabetic children, who were exposed to nitrate in 594 drinking water supplies in Scotland and parts of central England. This study included 886 and 1376 English and the Scottish children less than 15 years old that had been identified as people infected with this disease between 1986 and 1990. Monthly average concentrations of nitrate have been reported in drinking water as 22.94 and $2.07 \mathrm{mg}$ per liter in Scotland and England, respectively, during the same period (65). Similar studies in the Netherlands (66) and Italy (67) also showed that there is no relationship between different concentrations of nitrate and nitrite in drinking water and insulin-dependent type 1 diabetes mellitus. The results of the aforementioned studies showed that the data are limited and there are contradictions in this area, so in order to achieve a comprehensive and definitive diagnosis of the relationship between nitrate, nitrite and nitrosamine in the body and diabetes mellitus, a proper estimation should be done of the intake of these parameters through various foods and beverages.

\section{Benefits of Nitrate}

Despite the harms found in drinking water and foods containing nitrites and nitrates, studies conducted in the recent years have indicated the benefits of nitrite and nitrate. Lundberg et al. hypothesized in their 2006 study that the inorganic nitrate and nitrite, which enters the body through the consumption of vegetables leads to positive effects on health through biological conversion to nitrite and nitric oxide and secondary reaction products, such as nitrous/nitrile. In fact, by various bacteria in the oral cavity, nitrate in food is converted to nitrite and nitrite oxide and these compounds have protective effects on the cardiovascular system (68). Nitrogen oxide (No) is the most important molecule that plays a role in the regulation of blood pressure and maintains homeostasis of vessels (69). Benjamin et al. showed that the antibacterial effect of stomach acid has significantly increased in the presence of nitrite in the saliva (70). Nitrate naturally exists in breast milk, it has been shown that low concentrations of nitrate is not only a pollutant but also plays a role as an important nutritious element in the protection of children. It has been suggested that breast milk for infants is the only nutrient for 6 months and after this period milk along with food supplements exists in the diet of children up to the age of 2 (71). Nutritional and immunological benefits of breast milk have been demonstrated for infants (72). Several studies have shown that high concentrations of nitrite and nitrate exist in breast milk. Ohta et al. showed that high concentrations of nitrates and nitrites (10 to 70 mg per lit) are present in Japanese mother's milk during 1 to 8 days (73). The sources of nitrate and nitrite are unknown in breast milk. However, the presence of nitrite and nitrate in breast milk is an evidence of physiological benefits in protection of baby's digestive system and also is an evidence of adaption of the human body consumption of nitrite and nitrate through the diet from birth. Therefore, a significant risk is not possible for humans due to the nitrate and nitrite that naturally exist in foods (74). Nitrate and nitrite, as preservatives, are used to stabilize the color, create fragrant, control food spoilage by oxidation of lipids, and as anti-bacteria in food. Nitrate is considered as the processor element when first reduced to nitrite (75). Studies on the role of nitrate, as a factor that inhabits the growth of other microorganisms, are growing. Models used to predict bacteria growth of pathogens, such as Listeria monocytogenes, have shown that the effectiveness of antibiotics, such as sodium lactate and sodium di acetate, increase in the presence of nitrite. Moreover, the speed of growth of pathogens, Listeria monocytogenes, Escherichia coli and Bacillus cereus, has decreased in the presence of nitrate that is used in processing of meat products.

The adverse effects and benefits of nitrate and nitrite in drinking water and food on human health is mentioned in Table 1.

\section{Conclusion}

The issue of groundwater contamination to nitrate and nitrite are raised all over the world, but the risk is not clear. Studies have shown that many adverse health effects, caused by chronic exposure to low concentrations of nitrate in drinking water and since WHO guidelines suggested the prevention of methemoglobinemia disease that's why we can say that the maximum allowable concentration set for this contaminants are still being debated. The results of the present study showed that the consumption of drinking water and food containing high concentrations of nitrates and nitrites can cause diseases, such as cancer, methemoglobinemia, enlargement of the thyroid gland, and diabetes mellitus. The positive effects of 
Table 1. Adverse Effects and Benefits of Nitrate and Nitrite in Drinking Water and Food on Human Health

\begin{tabular}{|c|c|}
\hline $\begin{array}{l}\text { Effect } \\
\text { Adverse Effect }\end{array}$ & Lists \\
\hline \multirow{5}{*}{$\begin{array}{l}\text { Chronic effect (Carcinogenic } \\
\text { effect of nitrates and nitrites) }\end{array}$} & Gastrointestinal tract tumours \\
\hline & Non-Hodgkin’s lymphoma (NHL) \\
\hline & Urinary tract tumours \\
\hline & Brain tumours \\
\hline & Pancreas tumours \\
\hline \multirow{3}{*}{ Acute toxicity } & Methaemoglobinaemia \\
\hline & Mellitus diabetes \\
\hline & Effect on the thyroid gland \\
\hline \multirow{5}{*}{ Benefits Effect } & Protective effects on the cardiovascular system \\
\hline & Regulation of blood pressure and maintain Homeostasis of vessel \\
\hline & Plays a role as an important nutritious element in the protection of children \\
\hline & Nitrate and nitrite as preservatives are used to stabilize the color, create fragrant, control food spoilage \\
\hline & Nitrate as a factor that inhabits the growth of other micro organisms \\
\hline
\end{tabular}

low concentrations of nitrate and nitrite could have a protective effect on the cardiovascular system, blood pressure regulation and maintaining homeostasis (the stability) of vessels. Finally, it can be concluded that due to different opinions on the concentration of nitrates and nitrites that have beneficial and adverse effects on human health and due to the high cost of treating water contaminated with nitrite and nitrate, more research should be conducted in this area to make proper judgments about setting the standards and the concentration of nitrite and nitrate in drinking water.

Study limitations, flaws in existing data and multiple adverse side effects with the benefits of nitrate and nitrite in drinking water and food, suggests that comprehensive studies on this issue should be conducted.

\section{References}

1. Mesdaghi nia AR, Mahvi AH, Naseri S, Mohamadi AA, Shekarriz M, Alimohamadi M. Study of nitrate reduction from water using nanosized iron [In Persian]. Iran J Health Environ. 2011;4(3):313-20.

2. Gelberg KH, Church L, Casey G, London M, Roerig DS, Boyd J, et al. Nitrate levels in drinking water in rural New York State. Environ Res. 1999;80(1):34-40. doi: 10.1006/enrs.1998.3881. [PubMed: 9931225].

3. Sankararamakrishnan N, Sharma AK, Iyengar L. Contamination of nitrate and fluoride in ground water along the Ganges Alluvial Plain of Kanpur district, Uttar Pradesh, India. Environ Monit Assess. 2008;146(13):375-82. doi: 10.1007/s10661-007-0085-5. [PubMed: 18075779].

4. Suthar S, Bishnoi P, Singh S, Mutiyar PK, Nema AK, Patil NS. Nitrate contamination in groundwater of some rural areas of Rajasthan, India.J Hazard Mater. 2009;171(1-3):189-99. doi: 10.1016/j.jhazmat.2009.05.111. [PubMed: 19545944].
5. Costa JL, Massone H, Martı́ nez D, Suero EE, Vidal CM, Bedmar F. Nitrate contamination of a rural aquifer and accumulation in the unsaturated zone. Agric Water Manag. 2002;57(1):33-47. doi: 10.1016/s03783774(02)00036-7.

6. Kross BC, Hallberg GR, Bruner DR, Cherryholmes K, Johnson JK. The nitrate contamination of private well water in Iowa. Am JPublic Health. 1993;83(2):270-2. doi: 10.2105/AJPH.83.2.270. [PubMed: 8427340].

7. Hu K, Huang Y, Li H, Li B, Chen D, White RE. Spatial variability of shallow groundwater level, electrical conductivity and nitrate concentration, and risk assessment of nitrate contamination in North China Plain. Environ Int. 2005;31(6):896-903. doi: 10.1016/j.envint.2005.05.028. [PubMed: 16005970].

8. Mahvi AH, Nouri J, Babaei AA, Nabizadeh R. Agricultural activities impact on groundwater nitrate pollution. Int J Environ Sci Technol. 2013;2(1):41-7. doi: 10.1007/bf03325856.

9. Atafar Z, Mesdaghinia A, Nouri J, Homaee M, Yunesian M, Ahmadimoghaddam M, et al. Effect of fertilizer application on soil heavy metal concentration. Environ Monit Assess. 2010;160(1-4):83-9. doi: 10.1007/s10661-008-0659-x. [PubMed: 19058018].

10. Rotaru A, Răileanu P. Groundwater contamination from waste storage works. Environ Eng ManagJ. 2008;7(6):731-5.

11. Mahvi AH, Ebrahimi SJ, Mesdaghinia A, Gharibi H, Sowlat MH. Performance evaluation of a continuous bipolar electrocoagulation/electrooxidation-electroflotation (ECEO-EF) reactor designed for simultaneous removal of ammonia and phosphate from wastewater effluent. J Hazard Mater. 2011;192(3):1267-74. doi: 10.1016/j.jhazmat.2011.06.041. [PubMed: 21741172].

12. Wakida FT, Lerner DN. Non-agricultural sources of groundwater nitrate: a review and case study. Water Res. 2005;39(1):3-16. doi: 10.1016/j.watres.2004.07.026. [PubMed: 15607159].

13. Gharibi H, Mahvi AH, Nabizadeh R, Arabalibeik H, Yunesian M, Sowlat MH. A novel approach in water quality assessment based on fuzzy logic. J Environ Manage. 2012;112:87-95. doi: 10.1016/j.jenvman.2012.07.007. [PubMed: 22885368].

14. Yousefi N, Fatehizedeh A, Ghadiri K, Mirzaei N, Ashrafi SD, Mahvi AH. Application of nanofilter in removal of phosphate, fluoride and nitrite from groundwater. Desalination Water Treat. 2016;57(25):11782-8. doi: 10.1080/19443994.2015.1044914. 
15. Shahbazi P, Vaezi F, Mahvi AH, Naddaffi K, Rahmani AR. Nitrate removal from drinking water by point of use ion exchange.J Res Health Sci. 2010;10(2):91-7. [PubMed: 22911930].

16. Khazaei M, Nabizadeh R, Mahvi AH, Izanloo H, Ansari Tadi R, Gharagazloo F. Nitrogen and phosphorous removal from aerated lagoon effluent using horizontal roughing filter (HRF). Desalination Water Treat. 2016;57(12):5425-34. doi: 10.1080/19443994.2014.1003100.

17. Walker R. The metabolism of dietary nitrites and nitrates. Biochem Soc Trans. 1996;24(3):780-5. doi: 10.1042/bst0240780. [PubMed: 8878847].

18. Mensinga TT, Speijers GJ, Meulenbelt J. Health implications of exposure to environmental nitrogenous compounds. Toxicol Rev. 2003;22(1):41-51. doi: 10.2165/00139709-200322010-00005. [PubMed: 14579546].

19. Liebscher H, Hii B, McNaughton D. Nitrates and pesticides in the Abbotsford aquifer, southwestern British Columbia. 1992

20. Egboka BCE. Nitrate contamination of shallow groundwaters in Ontario, Canada. Sci Total Environ. 1984;35(1):53-70. doi: 10.1016/00489697(84)90368-1.

21. Duijvenbooden WV, Matthijsen AJCM, Speijers GJA, Went CFV, Apeldoorn MEV. Integrated Criteria Document Nitrate. National Institute of Public Health and Environmental Protection Report. 1989(758473012).

22. Gangolli SD, van den Brandt PA, Feron VJ, Janzowsky C, Koeman JH, Speijers GJ, et al. Nitrate, nitrite and N-nitroso compounds. Environ Toxicol Pharmacol. 1994;292(1):1-38. doi: 10.1016/0926-6917(94)90022-

23. Pennington JAT. Dietary exposure models for nitrates and nitrites. Food Control. 1998;9(6):385-95. doi: 10.1016/s0956-7135(98)00019-x.

24. Iarc Working Group on the Evaluation of Carcinogenic Risks to Humans . IARC monographs on the evaluation of carcinogenic risks to humans. Ingested nitrate and nitrite, and cyanobacterial peptide toxins. IARC Monogr Eval Carcinog Risks Hum. 2010;94:v-vii. [PubMed: 21141240]1-412.

25. Walker R. Nitrates, nitrites and N-nitrosocompounds: a review of the occurrence in food and diet and the toxicological implications. Food Addit Contam. 1990;7(6):717-68. doi: 10.1080/02652039009373938. [PubMed: 2079111].

26. Prospero JM, Savoie DL. Effect of continental sources on nitrate concentrations over the Pacific Ocean. Nature. 1989;339(6227):687-9. doi: 10.1038/339687a0.

27. Janssen LHJM, Visser H, Römer FG. Analysis of large scale sulphate, nitrate, chloride and ammonium concentrations in The Netherlands using an aerosol measuring network. Atmos Environ. 1989;23(12):278396. doi:10.1016/0004-6981(89)90559-3.

28. Lefebvre A, Eilers W, Chunn B. Environmental sustainability of canadian agriculture: Agri-environmental indicator report series-report\# 2. Ottawa, Canada: Agriculture and Agri-Food Canada; 2010.

29. Spiegelhalder B, Eisenbrand G, Preussmann R. Influence of dietary nitrate on nitrite content of human saliva: possible relevance to in vivo formation of N-nitroso compounds. Food Cosmet Toxicol. 1976;14(6):545-8. doi: 10.1016/S0015-6264(76)80005-3. [PubMed: 1017769].

30. Leaf CD, Wishnok JS, Tannenbaum SR. L-arginine is a precursor for nitrate biosynthesis in humans. Biochem Biophys Res Commun. 1989;163(2):1032-7. doi:10.1016/0006-291X(89)92325-5. [PubMed: 2783109].

31. Ohshima $\mathrm{H}$, Bartsch $\mathrm{H}$. Chronic infections and inflammatory processes as cancer risk factors: possible role of nitric oxide in carcinogenesis. Mutat Res. 1994;305(2):253-64. doi: 10.1016/00275107(94)90245-3. [PubMed: 7510036].

32. Tricker AR. N-nitroso compounds and man: sources of exposure, endogenous formation and occurrence in body fluids. Eur J Cancer Prev. 1997;6(3):226-68. doi: 10.1097/00008469-199706000-00003. [PubMed: 9306073].

33. Yang CY, Wu DC, Chang CC. Nitrate in drinking water and risk of death from colon cancer in Taiwan. Environ Int. 2007;33(5):649-53. doi: 10.1016/j.envint.2007.01.009. [PubMed: 17316804].
34. van Loon AJ, Botterweck AA, Goldbohm RA, Brants HA, van Klaveren $\mathrm{JD}$, van den Brandt PA. Intake of nitrate and nitrite and the risk of gastric cancer: a prospective cohort study. Br J Cancer. 1998;78(1):129-35. doi: 10.1038/bjc.1998.454. [PubMed: 9662263].

35. Knekt P, Jarvinen R, Dich J, Hakulinen T. Risk of colorectal and other gastro-intestinal cancers after exposure to nitrate, nitrite and $\mathrm{N}$ nitroso compounds: a follow-up study. Int J Cancer. 1999;80(6):8526. doi: 10.1002/(SICI)1097-0215(19990315)80:6<852::AID-IJC9>3.0.CO;2S. [PubMed: 10074917].

36. Palli D, Saieva C, Coppi C, Del Giudice G, Magagnotti C, Nesi G et al. O6-alkylguanines, dietary $\mathrm{N}$-nitroso compounds, and their precursors in gastric cancer. Nutr Cancer. 2001;39(1):42-9. doi: 10.1207/S15327914nc391_6. [PubMed: 11588901].

37. Jensen OM. Nitrate in drinking water and cancer in northern Jutland Denmark, with special reference to stomach cancer. Ecotoxicol Environ Saf. 1982;6(3):258-67. doi: 10.1016/0147-6513(82)90016-1. [PubMed: 7106030].

38. Morales-Suarez-Varela MM, Llopis-Gonzalez A, Tejerizo-Perez ML. Impact of nitrates in drinking water on cancer mortality in Valencia, Spain. Eur J Epidemiol. 1995;11(1):15-21. doi: 10.1007/BF01719941. [PubMed: 7489769].

39. Gulis G, Czompolyova M, Cerhan JR. An ecologic study of nitrate in municipal drinking water and cancer incidence in Trnava District, Slovakia. Environ Res. 2002;88(3):182-7. doi: 10.1006/enrs.2002.4331. [PubMed: 12051796].

40. Law G, Parslow R, McKinney P, Cartwright R. Non-Hodgkin's lymphoma and nitrate in drinking water: a study in Yorkshire, United Kingdom. J Epidemiol Community Health. 1999;53(6):383-4. doi: 10.1136/jech.53.6.383. [PubMed: 10396486].

41. Cocco P, Broccia G, Aru G, Casula P, Muntoni S, Cantor KP, et al. Nitrate in community water supplies and incidence of nonHodgkin's lymphoma in Sardinia, Italy.J Epidemiol Community Health. 2003;57(7):510-1. doi: 10.1136/jech.57.7.510. [PubMed: 12821696].

42. Weyer PJ, Cerhan JR, Kross BC, Hallberg GR, Kantamneni J, Breuer $\mathrm{G}$, et al. Municipal drinking water nitrate level and cancer risk in older women: the Iowa Women's Health Study. Epidemiology. 2001;12(3):327-38. [PubMed: 11338313]

43. Ward MH, Mark SD, Cantor KP, Weisenburger DD, Correa-Villasenor A, Zahm SH. Drinking water nitrate and the risk of non-Hodgkin's lymphoma. Epidemiology. 1996;7(5):465-71. doi: 10.1097/00001648199609000-00003. [PubMed: 8862975].

44. Chiu HF, Tsai SS, Yang CY. Nitrate in drinking water and risk of death from bladder cancer: an ecological case-control study in Taiwan. J Toxicol Environ Health A. 2007;70(12):1000-4. doi: 10.1080/15287390601171801. [PubMed: 17497410].

45. Ward MH, Cantor KP, Riley D, Merkle S, Lynch CF. Nitrate in public water supplies and risk of bladder cancer. Epidemiology. 2003;14(2):18390. doi: 10.1097/01.EDE.0000050664.28048.DF. [PubMed: 12606884].

46. Zeegers MP, Selen RF, Kleinjans JC, Goldbohm RA, van den Brandt PA Nitrate intake does not influence bladder cancer risk: the Netherlands cohort study. Environ Health Perspect. 2006;114(10):1527-31. doi: 10.1289/ehp.9098. [PubMed: 17035137].

47. Volkmer BG, Ernst B, Simon J, Kuefer R, Bartsch GJ, Bach D, et al. Influence of nitrate levels in drinking water on urological malignancies: a community-based cohort study. BJU Int. 2005;95(7):972-6. doi: 10.1111/j.1464-410X.2005.05450.x. [PubMed: 15839916].

48. Ward MH, Rusiecki JA, Lynch CF, Cantor KP. Nitrate in public water supplies and the risk of renal cell carcinoma. Cancer Causes Control. 2007;18(10):1141-51. doi: 10.1007/s10552-007-9053-1. [PubMed: 17717631]

49. Michaud DS, Holick CN, Batchelor TT, Giovannucci E, Hunter DJ Prospective study of meat intake and dietary nitrates, nitrites, and nitrosamines and risk of adult glioma. Am J Clin Nutr. 2009;90(3):570-7. doi: 10.3945/ajcn.2008.27199. [PubMed: 19587083].

50. Aschebrook-Kilfoy B, Cross AJ, Stolzenberg-Solomon RZ, Schatzkin A, Hollenbeck AR, Sinha R, et al. Pancreatic cancer and exposure to 
dietary nitrate and nitrite in the NIH-AARP Diet and Health Study. Am J Epidemiol. 2011;174(3):305-15. doi: 10.1093/aje/kwr092. [PubMed: 21685410].

51. Mirvish SS. Nitrate Contamination. Springer; 1991. pp. 253-66.The sig nificance for human health of nitrate, nitrite and N-nitroso compounds.

52. Boink ABTJ, Vleeming W, Dormans JAMA, Speijers GJA. Managing Risks of Nitrates to Humans and the Environment. Special PublicationRoyal Society of Chemistry; 1999. pp. 317-26.Effects of nitrates and nitrites in experimental animals.

53. Gowans WJ. Fatal methaemoglobinaemia in a dental nurse. A case of sodium nitrite poisoning. Br J Gen Pract. 1990;40(340):470-1. [PubMed: 2271282].

54. Fan AM, Steinberg VE. Health implications of nitrate and nitrite in drinking water: an update on methemoglobinemia occurrence and reproductive and developmental toxicity. Regul Toxicol Pharmacol. 1996;23(1 Pt 1):35-43. doi:10.1006/rtph.1996.0006. [PubMed: 8628918].

55. Walton G. Survey of literature relating to infant methemoglobinemia due to nitrate-contaminated water. Am J Public Health Nations Health. 1951;41(8 Pt 1):986-96. [PubMed: 14847023].

56. Craun GF, Greathouse DG, Gunderson DH. Methaemoglobin levels in young children consuming high nitrate well water in the United States. Int J Epidemiol. 1981;10(4):309-17. doi: 10.1093/ije/10.4.309. [PubMed: 7327829].

57. Fewtrell L. Drinking-water nitrate, methemoglobinemia, and global burden of disease: a discussion. Environ Health Perspect. 2004;112(14):1371-4. doi: 10.1289/ehp.7216. [PubMed: 15471727].

58. Bruning-Fann CS, Kaneene JB. The effects of nitrate, nitrite and Nnitroso compounds on human health: a review. Vet Hum Toxicol. 1993;35(6):521-38. [PubMed: 8303822].

59. Sanchez-Echaniz J, Benito-Fernandez J, Mintegui-Raso S. Methemoglobinemia and consumption of vegetables in infants. Pediatrics. 2001;107(5):1024-8. doi:10.1542/peds.107.5.1024. [PubMed: 11331681].

60. van Maanen JM, van Dijk A, Mulder K, de Baets MH, Menheere PC, van der Heide $\mathrm{D}$, et al. Consumption of drinking water with high nitrate levels causes hypertrophy of the thyroid. Toxicol Lett. 1994;72(1-3):36574. doi: 10.1016/0378-4274(94)90050-7. [PubMed: 8202954]

61. Gatseva PD, Argirova MD. High-nitrate levels in drinking water may be a risk factor for thyroid dysfunction in children and pregnant women living in rural Bulgarian areas. Int J Hyg Environ Health. 2008;211(5 6):555-9. doi:10.1016/j.ijheh.2007.10.002. [PubMed:18164247].

62. Kostraba JN, Gay EC, Rewers M, Hamman RF. Nitrate levels in community drinking waters and risk of IDDM. An ecological analysis. Diabetes Care. 1992;15(11):1505-8. doi: 10.2337/diacare.15.11.1505. [PubMed 1468277].

63. Dahlquist GG, Blom LG, Persson LA, Sandstrom AI, Wall SG. Dietary factors and the risk of developing insulin dependent diabetes in child- hood. BMJ. 1990;30o(6735):1302-6. doi: 10.1136/bmj.300.6735.1302. [PubMed: 2369660].

64. Virtanen SM, Jaakkola L, Rasanen L, Ylonen K, Aro A, Lounamaa R, et al. Nitrate and nitrite intake and the risk for type 1 diabetes in Finnish children. Childhood Diabetes in Finland Study Group. Diabet Med. 1994;11(7):656-62. doi: 10.1111/j.1464-5491.1994.tb00328.x. [PubMed: 7955990].

65. Group PE. Nitrate in drinking water and childhood-onset insulindependent diabetes mellitus in Scotland and Central England. 1999

66. van Maanen JM, Albering HJ, de Kok TM, van Breda SG, Curfs DM, Vermeer IT, et al. Does the risk of childhood diabetes mellitus require revision of the guideline values for nitrate in drinking water? Environ Health Perspect. 2000;108(5):457-61. doi: 10.1289/ehp.00108457. [PubMed: 10811574]

67. Casu A, Carlini M, Contu A, Bottazzo GF, Songini M. Type 1 diabetes in sardinia is not linked to nitrate levels in drinking water. Diabetes Care. 2000;23(7):1043-4. doi:10.2337/diacare.23.7.1043. [PubMed:10895879].

68. Lundberg JO, Feelisch M, Bjorne H, Jansson EA, Weitzberg E. Cardioprotective effects of vegetables: is nitrate the answer? Nitric Oxide. 2006;15(4):359-62. doi: 10.1016/j.niox.2006.01.013. [PubMed: 16563818].

69. Yoshida K, Kasama K. Biotransformation of nitric oxide. Environ Health Perspect. 1987;73:201-5. doi: 10.1289/ehp.8773201. [PubMed: 3665863].

70. Benjamin N, O'Driscoll F, Dougall H, Duncan C, Smith L, Golden M, et al. Stomach NO synthesis. Nature. 1994;368(6471):502. doi: 10.1038/368502a0. [PubMed: 8139683].

71. Gartner LM, Morton J, Lawrence RA, Naylor AJ, O'Hare D, Schanler RJ, et al. Breastfeeding and the use of human milk. Pediatrics. 2005;115(2):496-506. doi: 10.1542/peds.2004-2491. [PubMed: 15687461].

72. James DC, Lessen R, American Dietetic A. Position of the American Dietetic Association: promoting and supporting breastfeeding. $J$ Am Diet Assoc. 2009;109(11):1926-42. doi: 10.1016/j.jada.2009.09.018. [PubMed: 19862847].

73. Ohta N, Tsukahara H, Ohshima Y, Nishii M, Ogawa Y, Sekine $\mathrm{K}$, et al. Nitric oxide metabolites and adrenomedullin in human breast milk. Early Hum Dev. 2004;78(1):61-5. doi: 10.1016/j.earlhumdev.2004.04.002. [PubMed: 15177673].

74. Hord NG, Ghannam IS, Garg HK, Berens PD, Bryan NS. Nitrate and nitrite content of human, formula, bovine, and soy milks: implications for dietary nitrite and nitrate recommendations. Breastfeed Med. 2011;6(6):393-9. doi: 10.1089/bfm.2010.0070. [PubMed: 20958096].

75. Sindelar JJ, Milkowski AL. Human safety controversies surrounding nitrate and nitrite in the diet. Nitric Oxide. 2012;26(4):259-66. doi: 10.1016/j.niox.2012.03.011. [PubMed: 22487433]. 